\title{
Sayur Bukan Menjadi Preferensi Makanan Remaja di Indonesia
}

\section{Vegetable is Not Food Preferences of Adolescents in Indonesia}

\author{
Phebe Hendra, Rita Suhadi, Dita Maria V, Christianus Heru S \\ Departemen Farmakologi dan Farmasi Klinik Fakultas Farmasi Universitas Sanata Dharma Yogyakarta
}

\begin{abstract}
ABSTRAK
Remaja dan perilaku akan makanan dan kesehatannya perlu mendapat perhatian utama. Perilaku tersebut akan berlanjut hingga usia dewasa. Penelitian ini bertujuan untuk melihat preferensi makanan pada remaja di Indonesia. Penelitian dengan desain potong lintang menggunakan kuesioner untuk melihat preferensi makanan remaja siswa sekolah menengah atas. Informasi yang diperoleh adalah preferensi makanan utama, minuman dan perilaku snack serta karateristik responden. Responden yang terlibat dalam penelitian sejumlah 774 orang. Ayam merupakan makanan utama yang disebutkan remaja di Indonesia dari 3 jenis makanan utama. Air putih dan biskuit merupakan preferensi minum dan dan snack yang dikonsumsi remaja di Indonesia, sedangkan sayur hanya dipilih oleh sebagian kecil remaja.
\end{abstract}

Kata Kunci: Makanan, preferensi, remaja

\section{ABSTRAK}

A population of special concern is adolescents and their behavior related to nutrition and health. Health behavior in adolescence often follows the person into adulthood. The purpose of this research was to determine the food preference of adolescents in Indonesia. In this cross-sectional study, data were obtained on the food preference of adolescent senior high school student using a questionnaire. Information was obtained on preference of mail meals, drinks and snacking as well as demographic characteristics of participants. Total study population was 774 respondents. Among of the 3 main meals, chicken was most frequently consumed by adolescents in Indonesia. Water and biscuit were the most preference of drink and snack of adolescents in Indonesia, respectively, while vegetables was less prefered by respondence.

Keywords: Adolescent, food, preference

Korespondensi: Phebe Hendra. Departemen Farmakologi dan Farmasi Klinik Fakultas Farmasi Universitas Sanata Dharma Yogyakarta Kampus III Universitas Sanata Dharma, Paingan, Maguwoharjo, Depok, Yogyakarta 55284 Tel. 081904256888 Email: phebe_hendra@usd.ac.id

DOI: http://dx.doi.org/10.21776/ub.jkb.2019.030.04.18 


\section{PENDAHULUAN}

Kebutuhan gizi seseorang dipengaruhi oleh perilaku pola makan. Kuantitas dan kualitas baik makanan maupun minuman yang dikonsumsi dapat mempengaruhi tingkat kesehatan individu dan masyarakat. Konsumsi gizi yang tidak optimal berkaitan dengan kesehatan yang buruk, yang dapat meningkatkan risiko penyakit tidak menular seperti hipertensi dan diabetes. Sebagian besar terjadinya penyakit tidak menular terkait gizi berhubungan dengan terjadinya kelebihan berat badan dan kegemukan akibat kelebihan gizi. Kelebihan gizi ini timbul akibat konsumsi asupan kaya energi, kaya lemak jenuh, gula dan garam tambahan, namun kekurangan asupan pangan bergizi seperti sayuran dan buah serta kurang melakukan aktivitas fisik(1).

Pada masa remaja (adolescence), masa terjadinya transisi dari kanak-kanak menuju dewasa, biasanya individu mengalami berbagai perubahan salah satunya perubahan perilaku. Salah satu bentuk perilaku pada masa remaja berupa perilaku makan dalam pemilihan jenis makanan. Oleh karena itu perlu perhatian khusus karena remaja merupakan kelompok usia yang rentan gizi (2). Pemilihan jenis makanan yang salah pada masa remaja dapat mempengaruhi kualitas hidup hingga usia dewasa. Hasil Riskesdas 2013 menunjukkan terjadi peningkatan prevalensi gemuk semua kelompok umur, terutama pada usia usia 16-18 tahun dari 1,4\% pada tahun 2007 menjadi 7,3\% pada tahun 2013(3).

Asupan makanan merupakan salah satu faktor penting yang mempengaruhi status gizi. Rokhmah et al., melaporkan status gizi siswi pesantren kota Batu ditentukan oleh tingkat kecukupan energi dan zat gizi makro (protein, lemak dan karbohidrat) ' (4). Pilihan asupan makanan pada remaja dipengaruhi oleh beberapa hal, seperti ketersediaan jajanan di lingkungan sekolah, teman sebaya, media/iklan, serta pengaruh orang tua dan keluarga. Keadaan ini akan berdampak pada penentuan preferensi makanan. Preferensi makanan dapat didefinisikan sebagai kesukaan seseorang terhadap suatu makanan dan menjadikan makanan tersebut dipilih untuk dikonsumsi (5). Gambaran preferensi makanan yang dikonsumsi untuk suatu kelompok tertentu juga merupakan salah satu indikator penting akan tercukupinya kebutuhan gizi.

Hingga saat ini, belum ada penelitian yang menggambarkan preferensi makanan pada remaja. Berdasarkan hal tersebut, perlu dilakukan penelitian untuk melihat preferensi makanan remaja di Indonesia. Diharapkan dengan mengetahui preferensi remaja, dapat diketahui kebutuhan gizi dan status kesehatan remaja di Indonesia.

\section{METODE}

Penelitian yang dilakukan merupakan penelitian observasional deskriptif dengan desain potong lintang (cross sectional). Penelitian ini telah mendapatkan surat keterangan kelaikan etik (ethical clearance) dari Komisi Etik Penelitian Kesehatan Fakultas Kedokteran Universitas Kristen Duta Wacana Yogyakarta dengan no 679/C.16/FK/2018. Responden pada penelitian menggunakan responden remaja siswa sekolah menengah atas (SMA) dari 4 kota besar, yang mewakili empat pulau besar di Indonesia (Palembang, Bali, Yogyakarta, dan Pontianak). Responden dipilih berdasarkan convenient sampling dengan target 200 responden per kota sehingga total responden sebanyak 800 subjek. Dalam pelaksanaan penelitian diperoleh sebanyak 774 responden. Pemilihan metode sampling ini berkaitan dengan keterbatasan ijin dan akses ke sekolah target. Kriteria inklusi responden adalah siswa SMA yang berusia 15-17 tahun yang bersedia ikut serta dalam penelitian dan menandatangani informed consent serta diukur berat badan, tinggi badan. Pengumpulan data dilakukan melalui pengisian kuesioner dan pengukuran langsung berat badan dan tinggi badan.

Instrumen kuesioner yang telah divalidasi digunakan untuk memperoleh data penelitian. Kalkulasi data makanan utama, minuman serta profil snack dihitung berdasarkan pada jenis yang disebutkan masing-masing responden remaja. Secara umum, responden menyebutkan 2-3 jenis makanan utama, minuman dan profil snack yang sering dikonsumsi. Eksklusi data dilakukan terhadap jenis makanan utama, minuman serta profil snack yang sedikit disebutkan oleh responden.

Data umur, jenis kelamin dan body mass index (BMI) diklasifikasikan dalam kategori. Kategori BMI menggunakan persentile. Data lainnya disajikan secara deskriptif dalam bentuk tabel. Perhitungan jumlah jenis makanan utama, minuman serta profil snack berdasarkan preferensi terbanyak yang disebutkan para responden. Nilai persentase dihitung berdasarkan jumlah data terhadap jumlah responden. Hasil disajikan dalam bentuk jumlah dan nilai persentase untuk masing-masing kota, selain itu juga dihitung jumlah dan persentase terhadap total responden.

\section{HASIL}

Karakteristik responden penelitian menunjukkan sebagian besar remaja siswa SMA $(56,2 \%)$ berusia 16 tahun tersaji pada Tabel 1. Prosentase responden laki-laki lebih besar daripada perempuan terlihat pada responden yang berasal dari kota Yogyakarta, Pontianak, dan Palembang, namun berbeda dengan responden Bali. Secara umum proporsi jumlah remaja laki-laki $(49,5 \%)$ dan perempuan $(50,5 \%)$ yang terlibat dalam penelitian ini sama banyak. Hampir sebagian besar responden remaja SMA $(89,9 \%)$ Palembang, Yogyakarta, Bali, dan Pontianak tinggal bersama orang tua. Hampir sebagian besar remaja Palembang menunjukkan BMI normal, diikuti BMI overweight, obese, dan underweight. Gambaran yang relatif sama juga terlihat pada remaja Bali. Pada remaja Yogyakarta menunjukkan sebagian besar BMI normal, diikuti overweight, underweight, dan obese. Pada remaja Pontianak sebagian besar menunjukkan BMI obese, diikuti normal, overweight, dan underweight.

Tabel 1. Karakteristik remaja berdasarkan umur, jenis kelamin, dan tempat tinggal

\begin{tabular}{lrrrrrrrrrr}
\hline \multirow{2}{*}{ Karakteristik } & \multicolumn{1}{c}{ Palembang } & \multicolumn{1}{c}{ Yogyakarta } & \multicolumn{3}{c}{ Bali } & \multicolumn{3}{c}{ Pontianak } & \multicolumn{2}{c}{ Total } \\
\cline { 2 - 11 } & $\mathbf{n}$ & $\%$ & $\mathbf{n}$ & $\%$ & $\mathbf{n}$ & $\%$ & $\mathbf{n}$ & $\%$ & $\mathbf{n}$ & $\%$ \\
\hline Umur & 2 & 0,8 & 0 & 0 & 0 & 0 & 0 & 0 & 2 & 0,3 \\
14 tahun & 33 & 12,6 & 36 & 13,8 & 89 & 42,8 & 8 & 18,2 & 166 & 21,4 \\
15 tahun & 164 & 62,8 & 129 & 49,4 & 113 & 54,3 & 29 & 65,9 & 435 & 56,2 \\
16 tahun & 59 & 22,6 & 89 & 34,1 & 6 & 2,9 & 6 & 13,6 & 160 & 20,7 \\
17 tahun & 3 & 1,1 & 7 & 2,7 & 0 & 0 & 1 & 2,3 & 11 & 1,4 \\
18 tahun & & & & & & & & & & \\
Jenis kelamin & & & & & & & & & & \\
$\quad$ Laki-laki & 132 & 50,6 & 144 & 55,2 & 78 & 37,5 & 29 & 65,9 & 383 & 49,5 \\
$\quad \begin{array}{l}\text { Perempuan } \\
\text { Tempat tinggal }\end{array}$ & 129 & 49,4 & 117 & 44,8 & 130 & 62,5 & 15 & 34,1 & 391 & 50,5 \\
$\quad$ Orang tua & 242 & 92,7 & 205 & 78,5 & 207 & 99,5 & 42 & 95,5 & 696 & 89,9 \\
$\quad$ Kos & 19 & 7,3 & 56 & 21,5 & 1 & 0,5 & 2 & 4,5 & 78 & 10,1 \\
\hline
\end{tabular}


Tabel 1. Karakteristik remaja berdasarkan umur, jenis kelamin, dan tempat tinggal (Lanjutan)

\begin{tabular}{lrcrcrrrrrrr}
\hline \multirow{2}{*}{ Karakteristik } & \multicolumn{1}{c}{ Palembang } & \multicolumn{1}{c}{ Yogyakarta } & \multicolumn{2}{c}{ Bali } & \multicolumn{1}{c}{ Pontianak } & \multicolumn{2}{c}{ Total } \\
\cline { 2 - 12 } & $\mathbf{n}$ & $\%$ & $\mathbf{n}$ & $\%$ & $\mathbf{n}$ & $\%$ & $\mathbf{n}$ & $\%$ & $\mathbf{n}$ & $\%$ \\
\hline BMI & & & & & & & & & & \\
Underweight & 26 & 10,0 & 31 & 11,9 & 8 & 3,8 & 4 & 9,1 & 69 & 8,9 \\
Normal & 158 & 60,5 & 174 & 66,7 & 152 & 73,1 & 11 & 25,0 & 495 & 64,0 \\
Overweight & 44 & 16,9 & 33 & 12,6 & 34 & 16,4 & 10 & 22,7 & 121 & 15,6 \\
Obese & 33 & 12,6 & 23 & 8,8 & 14 & 6,7 & 19 & 43,2 & 89 & 11,5 \\
\hline
\end{tabular}

Hasil penelitian preferensi jenis makanan responden remaja tersaji pada Tabel 2. Masing-masing kota memberikan gambaran preferensi jenis makanan utama yang relatif sama. Remaja Palembang menyebutkan ayam sebagai jenis makanan utama yang disukai $(37,2 \%)$, diikuti oleh nasi goreng $(33,3 \%)$ dan mie $(26,8 \%)$, sedangkan remaja Yogyakarta memilih berturut-turut ayam $(41,0 \%)$, mie (27,6\%), dan nasi goreng (24,5\%). Pada remaja Bali, ayam merupakan makanan yang disukai $(38,0 \%)$, diikuti oleh nasi goreng $(25,5 \%)$, dan mie (15,9\%). Remaja Pontianak menyatakan ayam sebagai jenis makanan yang disukai $(36,4 \%)$ diikuti oleh nasi goreng $(27,3 \%)$ dan mie $(20,5 \%)$.

Secara umum, ayam merupakan jenis makanan utama preferensi paling banyak yang disebutkan responden remaja $(38,6 \%)$, diikuti oleh nasi goreng $(27,9 \%)$, dan mie $(23,8 \%)$.

Tabel 2. Distribusi remaja berdasarkan jenis makanan utama dan asal daerah

\begin{tabular}{lrrrrrrrrrr}
\hline \multirow{2}{*}{ Jenis makanan } & \multicolumn{1}{c}{ Palembang Yogyakarta } & \multicolumn{3}{c}{ Bali } & \multicolumn{3}{c}{ Pontianak } & \multicolumn{2}{c}{ Total } \\
\cline { 2 - 13 } & \multicolumn{1}{c}{ \% } & \multicolumn{1}{c}{$\mathbf{n}$} & \multicolumn{1}{c}{$\%$} & $\mathbf{n}$ & $\%$ & $\mathbf{n}$ & $\%$ & $\mathbf{n}$ & $\%$ \\
\hline Bakso & 40 & 15,3 & 31 & 11,9 & 20 & 9,6 & 2 & 4,5 & 93 & 12,0 \\
Ikan & 50 & 19,2 & 9 & 3,4 & 17 & 8,2 & 0 & 0 & 76 & 9,8 \\
Sapi & 4 & 1,5 & 8 & 3,1 & 12 & 5,8 & 1 & 2,3 & 25 & 3,2 \\
Ayam & 97 & 37,2 & 107 & 41,0 & 79 & 38,0 & 16 & 36,4 & 299 & 38,6 \\
Babi & 5 & 1,9 & 11 & 4,2 & 25 & 12,0 & 0 & 0 & 41 & 5,3 \\
Telur & 11 & 4,2 & 26 & 10,0 & 8 & 3,8 & 2 & 4,5 & 47 & 6,1 \\
Seafood & 17 & 6,5 & 6 & 2,3 & 12 & 5,8 & 4 & 9,1 & 39 & 5,0 \\
Sayur & 36 & 13,8 & 48 & 18,4 & 32 & 15,4 & 9 & 20,5 & 125 & 16,1 \\
Junk food & 12 & 4,6 & 12 & 4,6 & 18 & 8,7 & 1 & 2,3 & 43 & 5,6 \\
Nasi goreng & 87 & 33,3 & 64 & 24,5 & 53 & 25,5 & 12 & 27,3 & 216 & 27,9 \\
Mie & 70 & 26,8 & 72 & 27,6 & 33 & 15,9 & 9 & 20,5 & 184 & 23,8 \\
\hline
\end{tabular}

Selain makanan, jenis minuman juga dapat mempengaruhi asupan gizi. Air putih merupakan jenis minuman yang banyak disebutkan remaja di Indonesia $(50,1 \%)$ (Tabel 3$)$. Preferensi 3 jenis minuman yang banyak dikonsumsi remaja di Palembang dan Bali berturut-turut air putih, susu dan teh manis. Menurut remaja di Yogyakarta dan Pontianak, air putih dan teh manis merupakan preferensi minuman pilihan, diikuti susu untuk remaja Yogyakarta, serta soda untuk remaja Pontianak.

Tabel 3. Distribusi remaja berdasarkan jenis minuman dan asal daerah

\begin{tabular}{|c|c|c|c|c|c|c|c|c|c|c|}
\hline \multirow{2}{*}{ Jenis minuman } & \multicolumn{2}{|c|}{ Palembang } & \multicolumn{2}{|c|}{ Yogyakarta } & \multicolumn{2}{|c|}{ Bali } & \multicolumn{2}{|c|}{ Pontianak } & \multicolumn{2}{|c|}{ Total } \\
\hline & $\mathbf{n}$ & $\%$ & $\mathbf{n}$ & $\%$ & $\mathbf{n}$ & $\%$ & $\mathbf{n}$ & $\%$ & $\mathrm{n}$ & $\%$ \\
\hline & 120 & 46,0 & 137 & & 108 & 51,9 & 23 & 52,3 & 338 & \\
\hline & 46 & 17,6 & 77 & 29,5 & 42 & 20,2 & 7 & 15,9 & 172 & 22,2 \\
\hline Soda & 16 & 6,1 & 29 & 11,1 & 26 & 12,5 & 11 & 25,0 & 82 & 10,6 \\
\hline
\end{tabular}

Tabel 3. Distribusi remaja berdasarkan jenis minuman dan asal daerah (Lanjutan)

\begin{tabular}{lrrrrrrrrrr}
\hline \multirow{2}{*}{ Jenis minuman } & \multicolumn{1}{c}{ Palembang } & \multicolumn{1}{c}{ Yogyakarta } & \multicolumn{3}{c}{ Bali } & \multicolumn{3}{c}{ Pontianak } & \multicolumn{2}{c}{ Total } \\
\cline { 2 - 11 } & \multicolumn{1}{c}{$\boldsymbol{n}$} & \multicolumn{1}{c}{$\mathbf{n}$} & \multicolumn{1}{c}{$\%$} & $\mathbf{n}$ & \multicolumn{1}{c}{$\%$} & \multicolumn{1}{c}{$\boldsymbol{n}$} & \multicolumn{1}{c}{$\boldsymbol{n}$} & \multicolumn{1}{c}{$\%$} \\
\hline Teh manis & 32 & 12,3 & 102 & 39,1 & 38 & 18,2 & 20 & 45,5 & 192 & 24,8 \\
Jus & 18 & 6,9 & 40 & 15.3 & 24 & 11,5 & 2 & 4,5 & 84 & 10,9 \\
Sirup & 3 & 1,1 & 12 & 4,6 & 5 & 2,4 & 2 & 4,5 & 22 & 2,8 \\
\hline
\end{tabular}

Hasil penelitian menunjukkan biskuit merupakan preferensi snack yang banyak disebutkan oleh responden (49\%), diikuti oleh kue/roti (38,9\%) dan mie/bakso/pasta (34,9\%) (Tabel 4). Remaja di Palembang dan Bali menunjukkan preferensi jenis snack yang sama, berturutturut biskuit; kue/roti; mie bakso/pasta. Remaja di Yogyakarta lebih memilih snack berturut-turut gorengan, biscuit dan kue/roti. Jenis snack yang sama juga disebutkan oleh remaja di Pontianak, namun mereka lebih memilih biskuit, gorengan dan kue/roti.

Pada penelitian diketahui, responden remaja di Palembang dan Pontianak biasa mengkonsumsi snack di rumah, sedangkan remaja di Yogyakarta dan Bali mengkonsumsi snack di luar rumah. Secara umum remaja di Indonesia mengkonsumsi snack di rumah lebih banyak daripada yang di luar rumah (44,1 vs 38,0\%). Preferensi responden remaja Palembang, Yogyakarta dan Bali yang mengkonsumsi snack secara bersama-sama lebih besar daripada sendiri, berturut-turut 59,8 vs 39,$8 ; 72,4$ vs 27,6 dan 65,9 vs $34,2 \%$. Remaja di Pontianak lebih menyukai mengkonsumsi snack sendiri $(56,8 \%)$ daripada bersamasama (43,2\%) (Tabel 4).

Tabel 4. Distribusi remaja berdasarkan pola snack dan asal daerah

\begin{tabular}{|c|c|c|c|c|c|c|c|c|c|c|}
\hline & \multicolumn{2}{|c|}{ Palembang } & \multicolumn{2}{|c|}{ Yogyakarta } & \multicolumn{2}{|c|}{ Bali } & \multicolumn{2}{|c|}{ Pontianak } & \multicolumn{2}{|c|}{ Total } \\
\hline & $\mathrm{n}$ & $\%$ & $\mathbf{n}$ & $\%$ & $\mathrm{n}$ & $\%$ & $\mathbf{n}$ & $\%$ & $\mathbf{n}$ & $\%$ \\
\hline \multicolumn{11}{|l|}{ Jenis snack } \\
\hline Buah segar & 44 & 16,9 & 77 & 29,5 & 53 & 25,5 & 8 & 18,2 & 182 & 23,5 \\
\hline Gorengan & 70 & 26,8 & 129 & 49,4 & 38 & 18,3 & 20 & 45,5 & 257 & 33,2 \\
\hline Biskuit & 117 & 44,8 & 122 & 46,7 & 115 & 55,3 & 25 & 56,8 & 379 & 49,0 \\
\hline Kue/roti & 106 & 40,6 & 98 & 37,5 & 78 & 37,5 & 19 & 43,2 & 301 & 38,9 \\
\hline $\begin{array}{l}\text { Mie/bakso/ } \\
\text { pasta }\end{array}$ & 99 & 37,9 & 87 & 33,3 & 74 & 35,6 & 10 & 22,7 & 270 & 34,9 \\
\hline
\end{tabular}

\begin{tabular}{lrrrrrrrrrr} 
Lokasi snacking & & & & & & & & & & \\
Rumah & 139 & 53,3 & 91 & 34,9 & 86 & 41,2 & 25 & 56,8 & 341 & 44,1 \\
Luar rumah & 86 & 33,0 & 105 & 40,2 & 93 & 44,7 & 10 & 22,7 & 294 & 38,0 \\
$\begin{array}{l}\text { Rumah dan } \\
\text { Luar rumah }\end{array}$ & 35 & 13,4 & 65 & 24,9 & 29 & 13,9 & 8 & 18,2 & 137 & 17,7 \\
$\begin{array}{l}\text { Tidak pernah } \\
\text { Saat snacking }\end{array}$ & 1 & 0,4 & 0 & 0,0 & 0 & 0,0 & 1 & 2,3 & 2 & 0,3 \\
$\begin{array}{l}\text { Sendiri } \\
\text { Bersama- }\end{array}$ & 104 & 39,8 & 72 & 27,6 & 71 & 34,1 & 25 & 56,8 & 272 & 35,1 \\
$\begin{array}{l}\text { sama } \\
\text { Tidak pernah }\end{array}$ & 156 & 59,8 & 189 & 72,4 & 137 & 65,9 & 19 & 43,2 & 501 & 64,7 \\
\hline & 1 & 0,4 & 0 & 0,0 & 0 & 0,0 & 0 & 0,0 & 1 & 0,1 \\
\hline
\end{tabular}

\section{DISKUSI}

Penelitian menemukan bahwa pada remaja SMA di empat kota besar Indonesia, faktor keluarga merupakan salah satu faktor yang memberikan pengaruh cukup besar dalam pemilihan jenis makanan yang akan dikonsumsi. Rahman et al., melaporkan adanya pengaruh remaja SMA di Palu yang masih tinggal bersama orang tua dengan perilaku makan yang bergizi(6). Pada penelitian ini, karakteristik responden 
menunjukkan sebagian besar remaja siswa SMA (56,2\%) berusia 16 tahun tinggal bersama orang tua dengan prosentase responden laki-laki lebih besar daripada perempuan, walaupun secara umum proporsi jumlah remaja laki-laki dan perempuan hampir sama banyak.

Secara umum, kualitas gizi dan kelengkapan zat gizi dipengaruhi oleh preferensi akan keanekaragaman jenis makanan yang dikonsumsi. Loliana dan Nadhiroh melaporkan sebagian besar remaja SMA Surabaya pada kelompok obesitas memiliki kecukupan energi, karbohidrat, protein dan lemak yang lebih tinggi dibandingkan remaja dengan remaja non obesitas (7). Hasil penelitian di SMA Yogyakarta menunjukkan faktor asupan energi, lemak dan karbohidrat yang bermakna akan kejadian obesitas (8). Remaja di India yang mengkonsumsi junk food $2 x /$ minggu mempunyai risiko overweight dan obesitas baik dyang lebih besar dibandingkan yang tidak mengkonsumsi (9). Hal yang sama juga terjadi pada remaja di Malang (10). Oleh karena itu perlu perhatian khusus akan asupan energi, karbohidrat, protein, lemak karena dapat berdampak pada kejadian obesitas.

Pada penelitian ini responden remaja terutama mengkonsumsi ayam, yang merupakan sumber protein. Remaja usia 14-18 tahun di Amerika juga menyebutkan ayam sebagai salah satu dari lima sumber energi utama yang biasa dikonsumsi (11). Hal yang berbeda terlihat pada hasil penelitian remaja Cleveland Amerika, dimana sebagian besar kalori diperoleh dari konsumsi karbohidrat, bukan protein (12). Protein sangat dibutuhkan dalam masa pertumbuhan. Salah satunya sebagai sumber energi mempertahankan sel atau jaringan yang sudah terbentuk dan untuk mengganti sel yang rusak. Sumber protein hewani yang direkomendasi bagi remaja adalah ikan daripada konsumsi daging. Selain sebagai sumber protein, ikan juga merupakan sumber asam lemak tidak jenuh dan sumber mikronutrien. Konsumsi daging dan unggas perlu perhatian karena mengandung kolesterol dalam jumlah yang relatif tinggi, yang dapat membahayakan kesehatan(1).

Sayuran merupakan salah satu jenis makanan beragam yang masuk dalam empat pilar prinsip gizi seimbang (1) namun hasil penelitian menunjukkan sayuran tidak termasuk dalam preferensi 3 jenis makanan utama yang dikonsumsi responden remaja. Sebagian besar responden tinggal dengan orang tua $(89,9 \%)$, namun ternyata peran orang tua/keluarga belum mampu memberikan pengaruh yang cukup dalam pemilihan sayuran sebagai salah satu preferensi jenis makanan utama. Hal yang sama juga pada sebagian besar remaja di Fiji sedikit mengkonsumsi sayuran (13). Hasil survei tahun 2015 juga menunjukkan hal yang sama, remaja Indonesia usia 16-19 tahun kurang mengkonsumsi sayuran $(97,1 \%)(14)$.

Preferensi jenis minuman pada masing-masing daerah di Indonesia menunjukkan perbedaan, walaupun air putih merupakan jenis minuman yang banyak disebutkan oleh responden. Hal ini sesuai dengan pedoman gizi seimbang, konsumsi air putih dalam jumlah cukup sangat dibutuhkan untuk menjaga kesehatan (1). Selain air putih, teh manis $(24,8 \%)$ dan susu $(22,2 \%)$ juga menjadi preferensi responden remaja. Jenis minuman soda, jus dan sirup

\section{DAFTAR PUSTAKA}

1. Kementerian Kesehatan Republik Indonesia. Peraturan Menteri Kesehatan Republik Indonesia bukan merupakan jenis minuman yang menjadi preferensi remaja di Indonesia. Hampir sebagian besar remaja SMK Bandung menunjukkan perilaku konsumsi minuman soda (soft drink) yang rendah (59,2\%) (15). Hal ini berbeda dengan hasil survei 2015, angka proporsi remaja SMA yang mengkonsumsi minuman bersoda cukup tinggi $(1,16)$.

Selain makanan dan minuman, snack atau makanan jajanan sudah menjadi bagian yang tidak terpisahkan dari kehidupan masyarakat serta budaya bagi segala kalangan usia termasuk para remaja SMA. Aini melaporkan remaja SMA di Semarang mengkonsumsi snack 4-6 kali dalam sehari (17). Hasil penelitian menunjukkan biskuit merupakan preferensi snack yang banyak disebutkan oleh responden. Wate et al., juga melaporkan biscuit sebagai salah satu jenis snack yang banyak dikonsumsi oleh remaja di Fiji (13). Remaja di Amerika menunjukkan peningkatan perilaku snacking, 3 snack perhari yang berkalori tinggi berupa makanan atau minuman rendah nilai nutrisi setiap harinya (18). Pramono dan Sulchan melaporkan snack dengan $>330$ kkal berkontribusi besar akan risiko terjadinya obesitas pada remaja. Berkaitan dengan kemungkinan terjadinya risiko obesitas, maka perlu ditentukan jumlah kalori snack yang dikonsumsi (19). Salah satu faktor yang dapat mempengaruhi kebiasaan mengkonsumsi snack pada anak dan remaja adalah lingkungan rumah atau sekolah $(20,21)$. Pada penelitian diketahui sebagian besar responden remaja mengkonsumsi snack di rumah daripada di luar rumah. Secara umum responden remaja di Indonesia lebih menyukai mengkonsumsi snack bersama-sama dibandingkan sendirian.

Pada penelitian ini diketahui preferensi makanan, minuman serta profil snack pada remaja di Indonesia. Secara umum, ada kemiripan preferensi 3 jenis makanan utama, jenis minuman serta snack pada responden masingmasing daerah, Palembang, Yogyakarta, Bali dan Pontianak. Remaja Indonesia mempunyai preferensi makanan utama ayam dan preferensi minum air putih. Biskuit merupakan preferensi snack yang dikonsumsi. Berdasarkan hasil yang diperoleh terlihat bahwa remaja Indonesia memiliki gizi yang cukup dengan tingkat kesehatan yang relatif baik, terlihat dari nilai BMI normal remaja sebesar $64 \%$. Meskipun demikian, beberapa hal yang perlu menjadi perhatian adalah BMI remaja overweight dan obese yang diperoleh sebesar 27,1\% serta sayuran bukan merupakan preferensi makanan utama pada remaja yang dapat memicu terjadi obesitas pada remaja.

Beberapa kelemahan pada penelitian ini adalah (1) jumlah responden remaja di Pontianak yang sedikit; (2) beberapa jenis makanan yang disebutkan responden tidak dapat dikategorikan secara jelas, seperti jenis makanan seafood dan ikan. Preferensi dipengaruhi banyak faktor, salah satunya sosial ekonomi, serta ketersediaan akses juga mempengaruhi. Oleh karena itu perlu penelitian lanjutan untuk mengetahui faktor yang mempengaruhi alasan pemilihan preferensi makanan pada remaja di Indonesia.

\section{UCAPAN TERIMAKASIH}

Ucapan terima kasih kami sampaikan kepada LPPM Universitas Sanata Dharma yang telah membantu dalam pendanaan penelitian ini.
Nomor 41 Tahun 2014 tentang Pedoman Gizi Seimbang. Jakarta: Kemenkes RI; 2014.

2. Todd AS, Street SJ, Ziviani J, Byrne NM, and Hills AP. 
Overweight and Obese Adolescent Girls: The Importance of Promoting Sensible Eating and Activity Behaviors from the Start of the Adolescent Period. International Journal of Environmental Research and Public Health. 2015; 12(2): 2306-2329.

3. Kementerian Kesehatan Republik Indonesia. Riset Kesehatan Dasar Riskesdas 2013. Jakarta: Kemenkes $\mathrm{RI} ; 2013$.

4. Rokhmah F, Muniroh L, dan Nindya TS. Hubungan Tingkat Kecukupan Energi dan Zat Gizi Makro dengan Status Gizi Siswi SMA di Pondok Pesantren Al-Izzah Kota Batu. Media Gizi Indonesia. 2016; 11(1): 94-100.

5. Vabø $\mathrm{M}$ and Hansen $\mathrm{H}$. The Relationship between Food Preferences and Food Choice: A Theoretical Discussion. International Journal of Business and Social Science. 2014; 5(7): 145-157.

6. Rahman N, Dewi NU, and Armawaty F. Faktor-Faktor yang Berhubungan dengan Perilaku Makan pada Remaja SMA Negeri 1 Palu. PREVENTIF: Jurnal Kesehatan Masyarakat. 2016; 7(1): 43-52.

7. Loliana N and Nadhiroh SR. Asupan dan Kecukupan Gizi antara Remaja Obesitas dengan Non Obesitas. Media Gizi Indonesia. 2015; 10(2): 141-145.

8. Kurdanti W, Suryani I, Syamsiatun $\mathrm{NH}$, et al. Faktorfaktor yang Mempengaruhi Kejadian Obesitas pada Remaja. Jurnal Gizi Klinik Indonesia. 2015; 11(4): 179-190.

9. Joshi HA, Jethva VJ, and Patel N. Changing Food Pattern in Adolescents and Impact on Health. International Journal of Medical Science and Public Health. 2014; 3(12): 1442-1445.

10. Septiana P, Nugroho FA, dan Wilujeng CS. Konsumsi Junk Food dan Serat pada Remaja Putri Overweight dan Obesitas yang Indekos. Jurnal Kedokteran Brawijaya. 2018; 30(1): 61-67.

11. Reedy J and Krebs-Smith S. Dietary Sources of Energy, Solid Fats, and Added Sugars among Children and Adolescents in the United States.
Journal of the American Dietetic Association. 2010; 110(10): 1477-1484.

12. Weiss A, Xu F, Storfer-Isser A, Thomas A, leversLandis CE, and Redline S. The Association of Sleep Duration with Adolescents' Fat and Carbohydrate Consumption. Sleep. 2010; 33(9): 1201-1209.

13. Wate JT, Snowdon W, Millar L, et al. Adolescent Dietary Patterns in Fiji and their Relationships with Standardized Body Mass Index. The International Journal of Behavorial Nutrition and Physical Acitvity. 2013; 10(45): 1-12.

14. Kusumawardani N, Rachmalina S, Wiryawan $\mathrm{Y}$, et al. Perilaku Berisiko Kesehatan pada Pelajar SMP dan SMA di Indonesia. Jakarta: Badan Litbangkes Kementerian Kesehatan Rl; 2015.

15. Tania M. Hubungan Pengetahuan Remaja dengan Perilaku Konsumsi Minuman Ringan di SMKN 2 Baleendah Bandung. Jurnal Ilmu Keperawatan. 2016; 4(1): 19-25.

16. Arofah D and Hertanto WS. Konsumsi Soft Drink sebagai Faktor Risiko Terjadinya Obesitas pada Remaja USIA 15-17 tahun (Studi Kasus di SMUN 5 Semarang). Media Medika Muda. 2007; (4): 55-58.

17. Aini SN. Faktor Risiko yang Berhubungan dengan Kejadian Gizi Lebih pada Remaja di Perkotaan. Unnes Journal of Public Health. 2013; 2(1): 1-8.

18. Piernas $\mathrm{C}$ and Popkin BM. Trends in Snacking among U.S. Children. Health Affairs. 2010; 29(3): 398-404.

19. Pramono A dan Sulchan M. Kontribusi Makanan Jajan dan Aktivitas Fisik terhadap Kejadian Obesitas pada Remaja di Kota Semarang. Jurnal Gizi Indonesia. 2014; 37(2): 129-136.

20. Larson $\mathrm{N}$ and Story M. A Review of Environmental Influences on Food Choices. Annals of Behavioral Medicine. 2009; 38(1): 56-73.

21. Corrêa EN, Schmitz BAS, and de Vasconcelos FAG. Aspects of the Built Environment Associated with Obesity in Children and Adolescents: A Narrative Review. Revista de Nutrição. 2015; 28(3): 327-340. 